\title{
ДІАГНОСТИКА РІВНЯ СФОРМОВАНОСТІ ПРОФЕСІЙНОЇ КУЛЬТУРИ МАЙБУТНІХ ВИХОВАТЕЛІВ ЗАКЛАДІВ ДОШКІЛЬНОї ОСВІТИ
}

\author{
Вікторія Гальченко \\ кандидат психологічних наук, доцент, \\ доцент кафедри педагогіки іпсихології дошкільної освіти \\ Національний педагогічний університет імені М.П. Драгоманова \\ 01601, Україна, м. Київ, вул. Пирогова, 9 \\ vyktoryjaG@ukr.net, http://orcid.org/0000-0002-2865-7245
}

\author{
Людмила Семенча \\ кандидат психологічних наук, викладач психолого-педагогічнихдисциплін \\ Комунальний заклад «Нікопольський фаховий педагогічний коледж» \\ Дніпропетровської обласної ради \\ 53200, Україна, м. Нікополь, вул. Станіславського, 7 \\ semencha2010@ukr.net, http://orcid.org/0000-0002-2423-9767
}

\begin{abstract}
Анотація
Статтю присвячено вивченню професійної культури студентів - майбутніх вихователів закладів дошкільної освіти у процесі їхньої професійної підготовки у закладі вищої педагогічної освіти. Здійснено теоретичний аналіз психолого-педагогічної літератури 3 проблеми дослідження, розкрито сутність поняття «професійна культура майбутніх вихователів закладів дошкільної освіти». Запропоноване власне трактування поняття «професійна культура майбутнього вихователя закладу дошкільної освіти, а саме: професійна культура майбутнього вихователя - це наявність у педагога духовного багатства (високоморальних цінностей), яскраво вираженої творчої індивідуальності, готової та здатної до нововведень і перетворень; особливих особистісних якостей (гуманізму, любові до дітей, педагогічного оптимізму, толерантності, тактовності тощо); компетентностей педагогічної діяльності в галузі дошкільної освіти; зовнішньої естетичної привабливості. Визначено основні критерії формування професійної культури (духовно-творчий, когнітивний, мотиваційно-ціннісний, рефлексивно-перцептивний, операціональний). Описано рівні сформованості професійної культури майбутніх вихователів, а саме: початковий, адаптивний, репродуктивно-прогностичний, пошуково-творчий. Здійснено добір діагностичних методик за всіма критеріями. Розроблено авторську діагностичну методику «Професійна компетентність майбутнього вихователя закладу дошкільної освіти». Проведено діагностичне дослідження рівня сформованості професійної культури студентів спеціальності «Дошкільна освіта» факультету педагогіки i психології Національного педагогічного університету імені М.П. Драгоманова. В дослідженні застосовувалися теоретичні методи - аналізу, узагальнення, систематизації, порівняння; емпіричні методи - спостереження, анкетування, бесіда; а також діагностичні методики, спрямовані на виявлення рівня сформованості професійної культури майбутніх вихователів закладів дошкільної освіти. Здійснено аналіз результатів діагностичного дослідження. Виявлено недостатній рівень сформованості професійної культури майбутніх вихователів закладів дошкільної освіти, особливо за духовнотворчим та рефлексивно-перцептивним компонентами. Накреслено перспективи подальших досліджень, які полягають у розробці та впровадженні в освітній процес закладів вищої педагогічної освіти технології формування професійної культури майбутніх вихователів закладів дошкільної освіти.
\end{abstract}


Ключові слова: професійна культура, педагогічна культура, формування, діагностика, компоненти професійної культури, рівні, майбутні вихователі закладів дошкільної освіти.

\section{Вступ}

В складних умовах сьогодення ресурсом професійної діяльності фахівця дошкільної освіти є не стільки вузькоспеціальні знання, вміння, навички, засвоєння професійних методик, скільки загальна і професійна культура, які забезпечують саморозвиток особистості, вихід за межі нормативності, здатність створювати нове й передавати наступному поколінню смисложиттєві цінності.

Якщо розглядати культуру з точки зору філософських парадигм, то культура $є$ як умовою, так і результатом існування й розвитку людського суспільства. Культура завжди була предметом глибокого інтересу й ретельного вивчення філософів різних часів. Яскравими в цьому напрямі $є$ роботи німецьких філософів Ф. Шіллера та I. Канта, російських Я. Данілевского і В. Соловйова, сучасних зарубіжних дослідників А. Бергсона, А. Тойнбі, М. Вебера, К. Ясперса, А.Швейера та інших.

Сьогодні культура - багатоаспектне явище, з яким тісно взаємопов’язані такі сфери життєдіяльності людини, як праця, побут, дозвілля, менталітет тощо. Рівень культури особистості є визначальним у її подальшому життєвому шляху, виборі життєвих стратегій та моделюванні життєвого сценарію.

В даний час у багатьох психолого-педагогічних дослідженнях широко вивчаються особливості гармонійно розвиненої особистості, аналізуються основні фактори становлення нової людини, творчої особистості, здатної до самовдосконалення.

Дослідженню проблеми самореалізації та саморозвитку особистості у професійній діяльності присвячені психолого-педагогічні праці таких учених, як О. Андрієнко, Г. Бурма, І. Демічева, Ю. Долінська, О. Ларіна, Н. Литовченко, В. Чайка, Х. Шапаренко, Т. Шестакова та інші.

Аналіз особливостей розвитку ціннісно-смислової сфери особистості студентів відображений в роботах багатьох авторів: Г. Андрєєвої, Л. Анциферової, Б. Братуся, В. Гаврилова, Е. Зеєра, О. Зіневич, О. Леонтьєва, Д. Леонтьєва, Б. Ломова, Н. Нікандрова, А. Реана та ін.

Розглядаючи поняття культури особистості, ми прийшли до висновку, що культура особистості - це результат ії духовно-творчої діяльності, інтеріоризація зовнішніх цінностей у неповторний внутрішній світ людини. Зміст культури особистості формується у процесі історичного розвитку в межах конкретної епохи, соціальними умовами, основними видами діяльності, побутом, прагненням до творчості в усіх сферах життя. Культура особистості завжди індивідуальна, неповторна. Саме індивідуальність, оригінальність, вільне творче творення самого себе й навколишнього світу становлять найважливіші риси культури людини як особистості.

Сучасний підхід до вивчення проблеми формування професійної культури закладено в працях таких дослідників, як 3. Абросимова, К. Абульханова-Славська, А. Барабанщиков, В. Бенін, Є. Бєлозерцев, Е. Бондаревська, І. Зязюн, І. Ісаєв, Н. Кузьміна, Г. Сагач та ін.

Проблемою формування професійно-педагогічної культури займалися такі вчені, як Є. Бєлозерцев, В. Кан-Калік, Л. Колесніков, Н. Кузьміна, М. Левицький, М. Левін, Б. Лихачов, А. Мудрик, В. Сластьонін, Н. Шуркова, А. Щербаков та ін. 
Сучасні вітчизняні науковці, в межах окресленої проблеми, досліджували особливості рівня сформованості інформаційної культури (Л. Куземко, І. Луценко), умови формування професійної культури та педагогічних компетенцій вихователів у процесі фахової підготовки (Г. Бєлєнька, Н. Воропай, Л. Зданевич, К. Коновалова, Ю. Смолянко та ін.).

Як зазначають дослідники І. Зязюн, Г. Сагач, у змісті культури головним є не речі, а людина, суспільство. Культура пронизує всі аспекти життєдіяльності людей і передбачає регулювання їхньої спільної діяльності за допомогою певних норм і правил, які закріплені в традиціях народу, знакових та символічних системах (Зазюн, Сагач, 1995: 6 ).

Мета нашого дослідження полягає у розкритті сутності поняття «професійна культура майбутніх вихователів ЗДО», визначенні ії основних компонентів та рівнів, описі результатів діагностики рівня сформованості професійної культури майбутніх вихователів.

Завдання дослідження: 1) здійснити аналіз наукової літератури з обраної проблеми; 2) провести діагностичне дослідження, спрямоване на виявлення рівня сформованості професійної культури у майбутніх вихователів ЗДО; 3) здійснити кількісно-якісний аналіз результатів діагностичного дослідження.

\section{Методи дослідження}

В дослідженні застосовувалися теоретичні методи - аналізу, узагальнення, систематизації, порівняння; емпіричні методи - спостереження, анкетування, бесіда; а також діагностичні методики, спрямовані на виявлення рівня сформованості професійної культури студентів - майбутніх вихователів закладів дошкільної освіти.

Для діагностичного дослідження нами було підібрано/розроблено та застосовано наступні методики за відповідними компонентами:

1. Духовно-творчий компонент.

Нами було застосовано дві методики: самооцінка творчого потенціалу особистості (Тест С. Медніка) та методика виявлення духовних цінностей «Здійснення бажань» (Е. Помиткіна).

Мета першого етапу діагностичного дослідження за духовно-творчим компонентом полягала у виявленні рівня творчого потенціалу студентів, а саме: виявити їхню допитливість, віру в себе, ступінь зосередженості, прагнення бути незалежним тощо. Другим етапом було виявлення рівня духовності у досліджуваних як здатності орієнтуватися на найвищі гуманістичні цінності у своєму житті та в подальшій педагогічній діяльності.

2. Когнітивний компонент.

Діагностичне дослідження за когнітивним компонентом проводилося за допомогою розробленого нами тесту «Професійна компетентність майбутнього вихователя ЗДО» (В. Гальченко, авторська методика).

Метою авторської методики було з'ясувати рівень наявних у студентів знань щодо професії вихователя, розуміння специфіки педагогічної діяльності, психолого-педагогічного підгрунтя роботи з дітьми дошкільного віку.

3. Мотиваційно-ціннісний компонент.

Для з'ясування рівня сформованості професійної культури майбутніх вихователів за мотиваційно-ціннісним компонентом було застосовано методику «Самооцінка здатності до самоосвіти і саморозвитку особистості» (Ю. Орлова). 
Мета цієї методики полягала у виявленні у досліджуваних прагнення до постійного саморозвитку та самоосвіти, рівня мотивації до майбутньої педагогічної діяльності та бажання здобувати базові та додаткові знання за спеціальністю «Дошкільна освіта».

\section{4. Периептивно-рефлексивний компонент.}

Вивчення перцептивно-рефлексивних здатностей студентів здійснювалося нами за допомогою діагностики соціальної емпатії (Н. Фетіскіна).

Метою діагностики було виявлення здатності у майбутніх вихователів до здійснення соціальної перцепції, зокрема, вміння бачити себе очима інших, робити глибокий самоаналіз, співчувати та співпереживати, розуміти партнерів по спілкуванню, сприяти створенню позитивного психологічного клімату в колективі.

5. І Інструментальний компонент.

Діагностика за інструментальним компонентом проводилася шляхом застосування тесту «Комунікативні й організаторські здібності» (В. Синявського, В. Федоришина).

Мета тестування полягала у виявленні рівня комунікативних та організаторських здібностей студентів як обов'язкової умови успішної роботи з майбутніми вихованцями, їхніми батьками та колегами в закладі дошкільної освіти.

\section{Результати та дискусії}

Поняття професійної культури було запропоноване I. Ісаєвим. На думку вченого, професійна культура - спосіб творчої самореалізації особистості викладача в різноманітних видах педагогічної діяльності та спілкування, спрямованих на освоєння, передачу та створення педагогічних цінностей i технологій. Структурними компонентами професійної культури викладача, за І. Ісаєвим, є аксіологічний, технологічний і особистісно-творчий (Исаев, 2004).

У свою чергу, до компонентів професійно-педагогічної культури О. Головіна відносить професійну майстерність (володіння професійними знаннями, професійними вміннями, позиція педагога щодо праці, себе, результатів праці, мислення, рефлексія, самооцінка, цілепокладання, такт); світоглядний компонент, який включає в себе професійно-педагогічні переконання, інтереси, ціннісні орієнтації у професійно-педагогічній сфері; моральний компонент - етичні норми ділових відносин, моральні почуття, теоретичні, етичні знання (Головина, 2005). Особливу роль відіграють етичні знання майбутнього вихователя у міжкультурних відносинах, у процесі виховання дітей - представників різних етнічних груп.

Ми поділяємо думку В. Радула, В. Кравцова, М. Михайліченка, які розглядають професійну культуру як поняття, що найбільш повно відображає професійний розвиток особистості педагога та його діяльність у професійній сфері, та вважають, що «професійна культура вчителя є складовою його загальної культури, складним утворенням у цілісній структурі особистості, що характеризує всю сукупність відносин у сфері педагогічної діяльності та відповідний розвиток індивідуальних професійно значущих здібностей, розумових, психологічних та фізичних якостей, мотиваційної сфери, забезпечує високу якість і позитивне ставлення до професійної діяльності» (Радула, Кравцова \& Михайліченко, 2005: $85)$.

На нашу думку, позитивне ставлення до професійної діяльності формується лише за умови створення сприятливого психологічного клімату під час навчання майбутніх вихователів у вищому навчальному закладі. Зокрема, на необхідності створення позитивного психологічного клімату у процесі професійної підготовки студентів наголошують зарубіжні дослідники, які стверджують, що «студенти вчаться, коли вони відчувають себе в безпеці, 
пов'язані з навчальним співтовариством, і більш мотивовані та залучені, коли вони навчаються в середовищі, яке характеризується позитивними структурами відносинами (Вестон, Отт \& Роджер, 2018).

I. Зязюн та Г. Сагач важливими показниками професійної культури вчителя вважають системний світогляд, модельне мислення, праксеологічну, рефлексивну та інформаційну озброєність, компетентність спілкування і управління, конкретно-предметні знання тощо (Зазюн \& Сагач, 1995).

Професійна культура майбутнього педагога тісно пов'язана з поняттям педагогічної культури. На думку Н. Павелко, під культурою також розуміються творчі здібності, внутрішні сили людини, іiі потенційні можливості. Предметом дослідження в межах методологічного підходу дослідниця вважає характеристику культури як універсальної властивості суспільного життя людей (Павелко, 2004).

Якщо розглядати освітянські погляди на педагогічну культуру, то варто досліджувати iї як сутнісну характеристику середовища, особливості педагогічної системи, як процес руху до нового якісного стану (Г. Звездунових, Є. Захарченко). В індивідуально-особистісному підході педагогічну культуру трактують як прояв сутнісних властивостей особистості, іiі професійної діяльності та спілкування викладача (А. Барабанщиков, Т. Білоусова, Н. Воробйов, Т. Іванова, С. Соболєва).

Погоджуємося $з$ думкою зарубіжних дослідників, які, моделюючи образ ідеального педагога, наголошують, що ця «ідеальність» цілком залежить від того, як сприймають та оцінюють його учні. Вчені зазначають, що «...справжня робота проходить через ці різні точки зору, коли дитина крутить калейдоскопом, в тому сенсі, що висвітлює ті точки зору, які сприяють побудові уявної ідеалізованої моделі досконалості вчителів» (Морено \& Ху Аренас, 2020).

3 точки зору вчених Т. Білоусової, Є. Бондаревської, педагогічна культура - це сутнісна характеристика особистості та діяльності педагога, це система педагогічних цінностей, способів діяльності і професійної поведінки вчителя. Науковці виділяють такі компоненти педагогічної культури: гуманістична педагогічна позиція та особистісні якості; професійні знання і культура педагогічного мислення; професійні вміння і творчий характер педагогічної діяльності; саморегуляція особистості й культура професійної поведінки педагога; активна педагогічна позиція (віра у можливості виховання, переконаність у громадській значущості професії, активність у захисті інтересів учня тощо); здатність самостійно приймати рішення в будь-якій ситуації (Белоусова, 1989).

Досліджуючи специфіку формування професійної культури у студентів спеціальності «Дошкільна освіта», нами було сформульоване наступне визначення: «професійна культура майбутнього вихователя - це наявність духовного багатства (високоморальних цінностей), яскраво вираженої творчої індивідуальності, готової та здатної до нововведень і перетворень; особливих особистісних якостей (гуманізму, любові до дітей, педагогічного оптимізму, толерантності, тактовності, доброзичливості тощо); знань, умінь та навичок педагогічної діяльності в галузі дошкільної освіти; зовнішньої естетичної привабливості» (Гальченко \& Семенча, 2020).

Е. Биркеланд, С. Одемотланд у своїх дослідженнях підкреслюють важливість такого компоненту професійної культури майбутніх вихователів, як рефлексивність. На їхню думку, «рефлексивність виступає в міжкультурній освіті як найважливіший актив. Однак... необхідно 
кинути виклик поняттям самоспоглядання і саморефлексії, які можуть дати суб'єкту свободу як мислячій істоті» (Биркеланд \& Одемотланд, 2018).

Не менш важливу роль відіграють емоції вихователя, особливо у міжкультурному середовищі, коли вихованці є представниками різних етнічних груп. На цьому наголошує у своїх дослідженнях К. Йокікокко, а саме: емоції є життєво важливою частиною будь-яких змін i, таким чином, вони відіграють важливу роль в процесі міжкультурного навчання вчителів (Йокікокко, 2016).

Беручи до уваги вищесказане, ми прийшли до висновку, що професійна культура - це багаторівневе та інтегроване утворення, що містить у собі такі компоненти, як:

1. Духовно-творчий компонент (високий рівень духовності та креативності, здатність до саморегуляції та саморозвитку, певним чином сформовані життєві стратегії, цілі, плани, проекти, навички життєтворчості як провідні характеристики творчої індивідуальності студента).

2. Когнітивний компонент (активне ставлення до навчально-пізнавальної діяльності, намагання глибше проникнути у сутність професії педагога дошкільної освіти).

3. Мотиваційно-ціннісний (особистісне ставлення майбутнього спеціаліста до обраної професії, визначення ії місця у загальній структурі професій, визначення провідної мотивації у роботі вихователя - гуманне ставлення до дитини, віра в їі сили та можливості).

4. Рефлексивно-перцептивний (здатність до рефлексії, самопізнання, пізнання й розуміння інших людей, високий рівень емпатії)

5. Інструментальний (життєвий досвід, організаторські здібності, наявність набутих у процесі навчання у ЗВО знань, умінь та навичок професійної діяльності, комунікативна компетентність) (Гальченко, 2019).

Якщо ще глибше розглянути структуру феномену педагогічної культури, то дослідники пропонують різні інтерпретації. Зокрема, Н. Павелко до структури педагогічної культури включає такі рівні ऑї вивчення: соціально-педагогічний, науково-педагогічний, професійнопедагогічний, особистісний.

Важливими для нашого дослідження виявилися рівні професійно-педагогічної культури, визначені вченим I. Ісаєвим, а саме: адаптивний, репродуктивний, евристичний, креативний (Исаев, 2004). Саме вони послугували основою виділених нами рівнів сформованості професійної культури майбутніх вихователів ЗДО - початкового, адаптивного, репродуктивно-прогностичного та пошуково-творчого. Детальніше опишемо ці рівні:

1) Початковий (студент має не стійкі, уривчасті уявлення про професію вихователя, не розуміє мети та завдань майбутньої педагогічної діяльності, не виявляє творчості, у нього не розвинені рефлексія та прагнення до професійного саморозвитку).

2) Адаптивний (студент має загальне уявлення про професію вихователя, мета та завдання майбутньої педагогічної діяльності студентом визначаються в узагальненому вигляді, досить рідко виявляє творчість, рефлексію та активність щодо професійного саморозвитку).

3) Репродуктивно-прогностичний (студент має стійке ціннісне ставлення до професії вихователя, розуміє мету та завдання майбутньої педагогічної діяльності, має прагнення до професійного саморозвитку, демонструє елементи творчої діяльності в освітньому процесі, періодично проявляє рефлексивно-перцептивні вміння та здібності до планування заходів професійного самовдосконалення). 
4) Пошуково-творчий (студент характеризується стійкою цілеспрямованістю щодо розширення та поглиблення знань з обраної професії, усвідомлює не тільки мету і завдання педагогічної діяльності, а й ії значення, сприймає професію вихователя як покликання, виявляє стійку схильність до творчого пошуку, рефлексії, соціальної перцепції, професійного саморозвитку та творчої самореалізації).

Діагностика рівня сформованості професійної культури була проведена упродовж I семестру 2020-2021 навчального року зі студентами 2 курсу спеціальності «Дошкільна освіта» факультету педагогіки та психології НПУ імені М.П. Драгоманова. Кількість задіяних до експерименту студентів склала 58 осіб (усі жіночої статі). До експериментальної групи (далі ЕГ) було віднесено студентів групи 2А, до контрольної групи (далі КГ) - групи 2Б. Опишемо якісні та кількісні результати констатувального етапу експерименту.

У процесі діагностування студентів за першим, духовно-творчим компонентом спостерігалася загальна тенденція - кращі результати досліджувані демонстрували за творчою складовою, та низькі - за духовною. У процесі діагностики студентів з низьким (початковим) рівнем було виявлено по 20\% в ЕГ та КГ, 3 адаптивним (достатнім) рівнем - 60\% досліджуваних в ЕГ та 50\% в КГ, з репродуктивно-прогностичним (середнім) рівнем - 20\% студентів ЕГ та 30\% досліджуваних КГ, з пошуково-творчим (високим) рівнем не було виявлено жодного студента. На нашу думку, це засвідчує недостатній рівень духовного розвитку студентів, розуміння ними гуманістичного базису педагогічної діяльності, як наслідок, необхідність посилити формувальний вплив у цьому аспекті.

Наступним компонентом, за яким проводилася діагностика, був когнітивний. За цим компонентом виявилися кращі результати, оскільки студенти навчалися вже другий рік і здобули певну кількість знань під час вивчення психолого-педагогічних дисциплін та участі в культурно-виховних заходах професійного спрямування для того, щоб орієнтувати в обраній професії. Відсотковий розподіл досліджуваних виявився таким: студентів з початковим рівнем діагностовано $30 \%$ в ЕГ та $10 \%$ в КГ, з адаптивним рівнем - $30 \%$ майбутніх вихователів ЕГ та $40 \%$ досліджуваних КГ, з репродуктивно- прогностичним рівнем констатовано $20 \%$ студентів ЕГ та $30 \%$ КГ, з пошуково-творчим рівнем - по 20\% досліджуваних в обох групах.

Діагностика мотиваційно-ціннісного компоненту професійної культури засвідчила значно вищі результати порівняно із попередніми, а саме: студентів з початковим і адаптивним рівнями не було виявлено жодного в обох групах. При цьому досліджуваних з репродуктивнопрогностичним рівнем було констатовано 40\% в ЕГ та $60 \%$ у КГ, а 3 пошуково-творчим рівнем - 60\% у студентів ЕГ та 40\% у досліджуваних КГ. Вважаємо, що такі високі результати пов'язані 3 високою мотивацією студентів до майбутньої професійної діяльності, усвідомленим прагненням до саморозвитку та самовдосконалення.

Результати діагностики рівня сформованості рефлексивно-перцептивного компоненту професійної культури підтвердили думку про те, що студентам поки що важко вдається здійснювати саморефлексію та у повній мірі застосовувати механізми соціальної перцепції, зокрема, соціальної емпатії. Кількісний аналіз зафіксував наступне співвідношення відсоткових значень за 4-ма рівнями: студентів з початковим рівнем було виявлено 10\% в ЕГ та жодного в КГ, 3 адаптивним рівнем - 30\% досліджуваних в ЕГ та $40 \%$ в КГ, на репродуктивно-прогностичному рівні опинилося 40\% студентів ЕГ та 50\% досліджуваних КГ, а найвищого (пошуково-творчого) рівня досягли 20\% студентів ЕГ та $10 \%$ КГ.

Останній компонент, який досліджувався - інструментальний, засвідчив високе прагнення значної частини майбутніх вихователів (майже 50\%) втілювати отримані 
компетентності під час навчання в закладі вищої освіти у своїй подальшій професійній діяльності, а також здатності до самоосвіти в цьому ж руслі, оскільки студентів з високим (пошуково-творчим) рівнем виявилося найбільше. Відобразимо результати у відсотках: студентів 3 початковим рівнем не було виявлено жодного в обох групах, студентів 3 адаптивним рівнем виявилося $40 \%$ в ЕГ та $20 \%$ в контрольній групі, 3 репродуктивнопрогностичним рівнем було виявлено $10 \%$ в ЕГ та $40 \%$ в КГ, а з пошуково-творчим рівнем $50 \%$ в ЕГ та $40 \%$ в КГ.

Таким чином, проведення констатувального етапу експерименту засвідчило наступні результати, показані в таблиці 1:

Таблиия 1

Зведена таблиця результатів констатувального етапу експерименту

\begin{tabular}{|c|c|c|}
\hline Група & Рівні & Результати у \% \\
\hline \multirow{2}{*}{ Експериментальна } & Пошуково-творчий & 30 \\
\cline { 2 - 3 } & Репродуктивно-прогностичний & 26 \\
\cline { 2 - 3 } & Адаптивний & 32 \\
\cline { 2 - 3 } & Початковий & 12 \\
\hline \multirow{2}{*}{ Контрольна } & Пошуково-творчий & 22 \\
\cline { 2 - 3 } & Репродуктивно-прогностичний & 42 \\
\cline { 2 - 3 } & Адаптивний & 30 \\
\cline { 2 - 3 } & Початковий & 6 \\
\hline
\end{tabular}

3 таблиці бачимо, що значна частина студентів мають початковий та адаптивний рівень сформованості основ професійної культури майбутнього вихователя $3 Д О(44 \%$ в експериментальній групі та 36\% в контрольній групі). При цьому студентів контрольної групи виявилося більше на репродуктивно-прогностичному рівні, а на пошуково-творчому рівні навпаки констатовано на $10 \%$ більше досліджуваних експериментальної групи, ніж контрольної групи.

\section{Висновки}

Отже, на основі результатів діагностичного дослідження ми прийшли до висновку, що рівень професійної культури майбутніх вихователів закладів дошкільної освіти недостатньо сформований. Додаткової уваги заслуговують духовно-творчий (особливо духовна складова) та перцептивно-рефлексивний (виявлені низькі та середні показники емпатіі) компоненти, за якими було констатовано нижчі результати.

Було виявлено, що значна частина студентів 2-го курсу спеціальності «Дошкільна освіта» мають початковий та адаптивний рівень сформованості основ професійної культури (44\% досліджуваних експериментальної групи та 36\% контрольної групи). Такі результати засвідчують необхідність розробки та впровадження технології формування професійної культури майбутніх вихователів закладів дошкільної освіти.

Таким чином, сьогодення вимагає від студентів спеціальності дошкільної освіти постійного самовдосконалення, підвищення рівня власної професійної культури з метою досягнення успіху в процесі подальшої взаємодії з вихованцями. На нашу думку, лише той педагог, який рухається шляхом особистісного зростання на принципах гуманізму, буде здатен сформувати подібні якості у дітей дошкільного віку. 
Відтак, підготовка фахівців дошкільної освіти має базуватися на побудові гуманістичного базису особистості студента - його спрямованості на загально людські цінності, духовність, моральність, толерантність, високий рівень загальної культури.

Перспективи подальших досліджень вбачаємо у розробці та впровадженні в освітній процес закладів вищої педагогічної освіти технології формування професійної культури майбутніх вихователів закладів дошкільної освіти.

\section{Література}

1. Белоусова, Т.Ф. (1989). Педагогическая практика как фактор формирования основ педагогической культуры. (Автореф. дис. канд. пед. наук). Ростов-на-Дону.

2. Гальченко, В.М., \& Семенча, Л.Г. (2020). Професійна культура як системоутворювальний фактор успішності майбутніх педагогів у професійній діяльності. The XXI century education: realities, challenges, development trends (Monograph). In prof. Hanna Tsvietkova (Ed). (c.509-522) Hameln : InterGING.

3. Гальченко, В.М. (2019). Творча індивідуальність як основа професійної культури майбутніх вихователів закладів дошкільної освіти. Professional development of a teacher in the light of European integration processes. In prof. Hanna Tsvietkova (Ed). (c. 531-549). Hameln : InterGING.

4. Головина, Е.С. (2005). Педагогическое содействие формированию профессиональной культуры будущих социальных педагогов в вузе. (Автореф. дис. канд. пед. наук). Екатеринбург.

5. Зязюн, І.А., \& Сагач, Г.М. (1997). Краса педагогічної діі. Київ : АПН України.

6. Исаев, И.Ф. (2004). Профессионально-педагогическая культура преподавателя. Москва : Академия.

7. Павелко, Н.И. (2004.) Культурологическая парадигма теории профессиональнопедагогической культуры преподавателя высшей школы (Дис. д-ра культурологии). Краснодар.

8. Радул, В.В., Кравцов, В.О., \& Михайліченко, М.В. (2007). Основи професійного становлення особистості сучасного вчителя (Навчальний посібник). Кіровоград : «ІмексЛТД».

9. Birkeland, A., \& Ødemotland, S. (2018). Disorienting Dilemmas - the Significance of Resistance and Disturbance in an Intercultural Program within Kindergarten Teacher Education. Integr. psych. Behav., 52, 377-387. doi: https://doi.org/10.1007/s12124-0189433-y

10. Jokikokko, K. (2016). Reframing Teachers' intercultural learning as an emotional process. Intercultural Education, 27(3), 217-230. doi: https://doi.org/10.1080/14675986.2016.1150648.

11. Weston, K., Ott, M., \& Rodger, S. (2018). Handbook of School-Based Mental Health Promotion. Cham : Springer.

12. Moreno, V.M. (2020). The Ideal Teacher Different Images. $\mathrm{Hu}$ Arenas. doi: https://doi.org/10.1007/s42087-020-00148-0

\section{References}

1. Belousova, T.F. (1989). Pedahohycheskaia praktyka kak faktor formyrovanyia osnov pedahohycheskoi kulturb [Pedagogical practice as a factor in the formation of the foundations of pedagogical culture]. Extended of Candidate's thesis. Rostov-na-Donu [in Russian]. 
2. Halchenko, V.M., \& Semencha, L.H. (2020). Profesiina kultura yak systemoutvoriuvalnyi faktor uspishnosti maibutnikh pedahohiv u profesiinii diialnosti [Professional culture as a systemforming factor of success of future teachers in professional activity]. The XXI century education: realities, challenges, development trends (Monograph). In prof. Hanna Tsvietkova (Ed). (c.509522) Hameln: InterGING. [in Ukrainian].

3. Halchenko, V.M. (2019). Tvorcha indyvidualnist yak osnova profesiinoi kultury maibutnikh vykhovateliv zakladiv doshkilnoi osvity [Creative individuality as a basis of professional culture of future educators of preschool educational institutions]. Professional development of a teacher in the light of European integration processes. In prof. Hanna Tsvietkova (Ed). (c. 531-549). Hameln : InterGING. [in Ukrainian].

4. Holovyna, E.S. (2005). Pedahohycheskoe sodeistvye formyrovanyiu professyonalnoi kulturb budushchykh sotsyalnskh pedahohov $\mathrm{v}$ vuze [Pedagogical assistance in the formation of the professional culture of future social teachers at the university]. Extended abstract of Candidate's thesis. Ekaterynburh. [in Russian]

5. Ziaziun, I.A., \& Sahach, H.M. (1997). Krasa pedahohichnoi dii [The beauty of pedagogical action]. Kyiv : APN Ukrainy [in Ukrainian].

6. Ysaev, Y.F. (2004). Professyonalno-pedahohycheskaia kultura prepodavatelia. [Professional and pedagogical culture of the teacher]. Moscow: Akademyia [in Russian].

7. Pavelko, N.Y. (2004). Kulturolohycheskaia paradyhma teoryy professyonalno-pedahohycheskoi kultury prepodavatelia vysshei shkoly [The culturological paradigm of the theory of professional and pedagogical culture of a higher school teacher]. Doctor's thesis. Krasnodar [in Russian].

8. Radul, V.V., Kravtsov, V.O., \& Mykhailichenko, M.V. (2007). Osnovy profesiinoho stanovlennia osobystosti suchasnoho vchytelia: Navchalnyi posibnyk [Fundamentals of professional development of the modern teacher].Kirovohrad :«Imeks-LTD» [in Ukrainian].

9. Birkeland, Å., \& Ødemotland, S. (2018). Disorienting Dilemmas - the Significance of Resistance and Disturbance in an Intercultural Program within Kindergarten Teacher Education. Integr. psych. Behave, 52, 377-387. doi: https://doi.org/10.1007/s12124-0189433-y

10. Jokikokko, K. (2016). Reframing Teachers' intercultural learning as an emotional process. Intercultural Education, 27(3). doi: https: //doi. org/ 10.1080/14675986.2016.1150648.

11. Weston, K., Ott, M., \& Rodger, S. (2018). Handbook of School-Based Mental Health Promotion. Cham : Springer.

12. Moreno, V.M. (2020). The Ideal Teacher Different Images. Hu Arenas. DOI : https://doi.org/10.1007/s42087-020-00148-0 


\title{
THE DIAGNOSTICS OF THE FUTURE PRESCHOOL TEACHERS' LEVEL OF PROFESSIONAL CULTURE FORMATION \\ Viktoriia Halchenko \\ PhD in Psychology, Associate Professor of theDepartment of Pedagogy and Psychology of Preschool Education \\ National Pedagogical Dragomanov University \\ 9, Pyrohov Str., Kyiv, Ukraine, 01601 \\ vyktoryjaG@ukr.net, http://orcid.org/0000-0002-2865-7245
}

\author{
Liudmyla Semencha \\ PhD in Psychology, Lecturer of Psychological and \\ Pedagogical Disciplines \\ Municipal Establishment "Nikopol Professional Pedagogical college" \\ of Dnipro Region Council \\ 7, Stanislavskogo Str, Nikopol, Ukraine, 53200 \\ Semencha2010@ukr.net, http://orcid.org/0000-0002-2423-9767
}

\begin{abstract}
The article is devoted to the study of the future preschool teachers' professional culture during the process of their professional training in the higher pedagogical education establishments. Theoretical analysis of psychological and pedagogical literature on the research problem has been carried out, the essence of the concept "the future preschool teachers" professional culture" has been revealed. The own interpritation of the concept "the future preschool teachers' professional culture" has been offered, namely: the future preschool teachers' professional culture - is the presence of the teacher's spiritual wealth (high moral values), a strong creative personality, ready and capable of innovation and transformation; special personal qualities (humanism, love for children, pedagogical optimism, tolerance, tact, etc.); competencies of pedagogical activity in the field of preschool education; external aesthetic appeal.The main criteria for the formation of professional culture (spiritual-creative, cognitive, motivational-value, reflexive-perceptual, operational) have been determined. The future teachers' levels of the professional culture formation are described, namely: initial, adaptive, reproductive-prognostic, searching-creative. The selection of diagnostic methods according to all criteria has been carried out. The author's diagnostic technique "The future preschool teachers' professional competence" has been developed. A diagnostic study of the level of the professional culture formation of the students of speciality "Preschool education" the faculty of Pedagogy and Psychology in National Pedagogical Dragomanov University students' has been undertaken. The study used theoretical methods - analysis, generalization, systematization, comparison; empirical methods - observation, questionnaire, conversation; as well as diagnostic techniques aimed at identifying the level of formation of professional culture of future educators of preschool education. The analysis of the results of diagnostic research has been carried out. The insufficient level of the future preschool teachers' professional culture formation has been revealed, especially according to spiritual-creative and reflexive-perceptual criteria. The prospects for the future research, which are to develop and implement in the educational process of the higher pedagogical education establishments the technology of the future preschool teachers' professional culture formation, have been outlined.

Keywords: professional culture, pedagogical culture, formation, diagnostics, components of the professional culture, levels, future educators of preschool institutions.
\end{abstract}

Подано 14.09.2021

Рекомендовано до друку 22.09.2021 